GYÖRGY SZERBHDRVÁTH *

Who's The Star Uf The Show?

On the Advantages and Disadvantages of and the

Relationships between Saciography, Sociology and

Literature
Intersections. EEJSP

1(2): 100-112.

DDI: 10.17356/ieejsp.vli2.113

http://intersections.tk.mta.hu

* [horvath.gyorgy@tk.mta.hu] (Center for Social Sciences, Hungarian

Academy of Sciences, Budapest)

\begin{abstract}
In this essay we try to recall that the history (but also the present) of Hungarian sociology or sociography is often represented as a 'crisishistory', and the question often arises of whether it can say anything relevant about the past and present, about the thing we call 'reality' or 'life'. It is also a resurfacing charge that Hungarian literature is in a crisis, too - that it doesn't say anything 'valid' or 'realistic' about Hungarian society. Nevertheless, here we examine whether Hungarian literature can inspire sociologists by showing topics which could be perhaps considered as taboos, and whether it can or could contribute to the formation of historical memory. Furthermore, we give a sketchy overview of its points of contact with social sciences, first of all with sociology and sociography, as well as with politics, and the role that professionals in these areas assign to themselves. It is done in a context in which humanities and arts are often charged by political actors of being useless. Some time ago, sociology and sociography were considered dangerous (as well as 'bourgeois') because of their critical stance, as disciplines that needed to be controlled. On the other hand, Hungarian writers are regularly accused of not dealing with Hungarian 'realities', while their role in the intellectual sphere is rapidly diminishing.
\end{abstract}




\section{Crisis discourses}

Recently, philosopher and public intellectual Gáspár Miklós Tamás criticised contemporary Hungarian Literature: "in the 1980s more significant literary works were published in six months than have been published in the quarter of a century since the change of regime" (Tamás, 2015). But how is the word 'significant' - as applied to literary works - to be operationalized? Sales figures are irrelevant, not just because of changing reading habits, but because, before 1990, under state socialism, the state supported certain works (and journals too) in such a way that they were published in over a hundred thousand copies, while prices were subsidized. Later, the state gradually withdrew its support from culture (as the revenues dedicated to this purpose from the lottery decreased). The National Cultural Fund's autonomy has also gradually decreased. Irrespective of whether left, liberal, or conservative (though the interpretation of these terms is increasingly problematic in Hungarian politics), opinion has often been that there are too many people in the humanities, and that we need engineers and skilled workers instead of communication studies graduates. But this narrative is well known here: during socialism some - in point of fact, leftist philosophers, such as Ágnes Heller or Mihály Vajda, were chased abroad. In 2011 another 'philosopher scandal' broke out: if philosophy needs only pen and paper, how did our renowned philosophers spend millions? At the end no misuse of funds was established. The 'scandal' had wide international resonance, as for instance Jürgen Habermas protested again a witch-hunt seemingly targeting left-liberal philosophers who had been dissidents under the previous, socialist regime.

Gáspár Miklós Tamás is not the only one to be nostalgic; the doyen of Hungarian literature, the 85-year-old Pál Réz, is of the same mind. The literary journal he edited, Holmi, ceased to exist in 2015, not only for financial reasons, but also because Réz and his colleagues at the editorial board saw no point in continuing, with no young generation to continue the journal founded in 1989. Réz regrets not having reached the standards of their ideal, the legendary journal Nyugat (1908-1941); moreover, rather pre-empting Tamás's words, he says "It is bizarre that during the communism there were more significant writers active than during the years of freedom". Réz adds: "most good Hungarian literature is left-wing, and thus it was necessary that the journal had more left-wing writers than right-wing ones, but we also had the latter" (Réz, 2015).

This sentence shows the extent to which Hungarian literature is embedded in politics. Being politically engaged is a sort of requirement on the Hungarian literary scene: a political confession which requires you to take your side.

Asked by political weekly Magyar Narancs after Tamás' article, elderly writers and literary historians agreed with him and Pál Réz, adding that though some important works have been created since 1990, these were written by authors who were active and wrote important works before 1990, like Péter Esterházy, Péter Nádas, György Spiró and Imre Kertész. Though Kertész's novel, Faithless, representing the Holocaust through the eyes of a 15-year-old boy, was first published in 1975, it remained almost unnoticed by Hungarian readers until its author won the Nobel Prize for Literature in 2002, while the active role of Hungarian authorities and citizens in the deportation and looting of Jews was also a taboo. (Today it is no longer 
a taboo, but in the Holocaust Memorial Year in 2014 the Hungarian government erected a statue - amidst heated professional debate and civil protests - which sends the message that only the German occupiers, not Hungarians, were responsible for the Hungarian Holocaust.)

Géza Morcsányi, former director of the eminent publishing company Magvetö, states that the impact of literature is gradually diminishing, for the following reasons: "the end of Enlightenment, the next crisis of multiculturalism, and here, in Eastern Europe, the end of the adult education specific to the socialist era, as well as a technological revolution which has democratized and profaned culture at the same time"; in general, the leading role of intellectuals is coming to an end (Hamvay, 2015).

However, famous Hungarian social historian Gábor Gyáni points out that while public history dominates public life, some important historians are propagandists and ideologists (that is, pseudo-academics) rather than historians; at the same time, "we can't forget about literature, which tells stories of history in a more enjoyable way (and with greater empathy) than historians' history does. Moreover, the historical novel is experiencing a renaissance in this country." He thinks that a good historical novel creates more excitement among readers, even among the intellectual public: "it emphasizes the constantly recurring situations of life, events strongly connected to a given historical time, and the connected experiences, and it can make the reader conscious of its timeliness through an experience of recognition” (Gyáni, 2013). Gyáni mentions György Spiró’s novel Captivity as well as Pál Závada’s oeuvre.

\section{Dysfunctional roles and searching for roles}

The role of the writer is a constant topic in Hungarian literature. In the 19th century, the era of romantic nationalism, it was self-evident that the role of the writer, of the poet, was to lead their nation through all odds, as one of the most influential poets of the period, Sándor Petőfi, wrote in 1847, and generate a Hungarian civic revolution. It is still an 'obligation' for the Hungarian writer to participate in the excavation of realities, irrespective of the actual political regime; this was the case after WW1, when the so-called 'populist' (leftist rural) writers went around villages and wrote sociographies (though sometimes right-wing writers would do the same), worried for the nation, exploring its decadence, writing about child poverty and single-child family models (when families decide to have only one child to keep the family property together). Committed socialist writers also tried to remain up-to-date and on-the-field, even though a school preferring aesthetic principles over political ones also emerged in Hungarian literature. Moreover, once upon a time, one of the most, if not the most, influential writer of the era, Kálmán Mikszáth (1847-1910), was not just president of the journalists' society, but a parliamentary deputy from 1887 till the end of his life. The other highly influential and popular writer of the period, Mór Jókai (1825-1904), was also a deputy.

Writers were not absent from the parliament of the socialist era either - though they also played a crucial role in initiating the 1956 revolution - and from the beginning of the 1980s they took a leading role in demolishing taboos, though not only in unmasking the dictatorship. They also took part in reviving open anti- 
Semitism: writer István Csurka, a founding figure of national radicalism and president of the Hungarian Truth and Life Party (Magyar Igazság és Élet Pártja) since 1993, spread such ideas in the parliament.

Sándor Csoóri’s infamous 1991 essay, entitled Nappali Hold (Daytime Moon), created a strong media response by reviving conspiracy theories in Hungarian public life about the Jews dominating Hungary.

Before the change of regime and during the transition, historians, philosophers and sociologists played an important role alongside writers. The first president of the free Republic of Hungary was writer Árpád Göncz, while others became officials, ambassadors, and members of parliament. There is no doubt that in the last two decades writers, along with social scientists and artists, have become pushed into the political background, and today professional politicians dominate this scene, in alliance with the oligarchs. ${ }^{1}$ In the last legislative period only one writer, Endre Kukorelly, was in parliament, for a total of 30 months; his work (2014) - Országházi divatok (Parliamentary Fashions) -, a diary-like autobiography, doesn't give us the same glimpses of this milieu as Jókai’s and Mikszáth's works, characterised as they are by their vitriolic tone and unveiling style. However, we can learn how crazy Hungarian politicians are about football: during big, international matches the parliament is practically empty, which is at the same time an excellent indicator of the state of democracy in this country.

\section{Where should sociologists stand?}

It is not our role to decide if Hungarian literature and social sciences - history, anthropology, or sociology - are in crisis. As we saw in the case of literature, the question is constantly on the table, but, as it is impossible to quantify it, only heavy statements can be made, which cannot be clearly verified or falsified: what we consider a masterpiece today might after some years become a boring piece of artwork, or vice versa. The question would be better approached from another perspective: that of the topics they avoid or address. We would like to cite the positive examples below to refute the argument that Hungarian writers since 1990 have been unable to write about the period following the change of regime, or that they have failed to write about deep social problems (the precedent to this is that writers in the West were expected to produce the 'grand novel' of the 1956 revolution) (Szilágyi, 2009).

In his 1997 lecture W. G. Sebald analysed the themes of German writers after WW2, and asked why they forgot to write about the bombings of German cities by the Allies (Sebald, 2014). Six hundred thousand civilians died during the bombings, and millions lost their homes. There are a few short stories and novels which dealt with the issue, but Sebald considers most of it low quality, Kitsch, a repertoire of common places with a Nazi rhetoric, a repetition of stereotypes. Thus, collective amnesia went hand in hand with the writers' silence (though he could add that of the

\footnotetext{
${ }^{1}$ Some writers call this new regime a cleptocracy (Schein, 2014).
} 
social sciences, too), and he asks what could be behind this. Were people ashamed, or did they want to forget?

Perhaps the same question could be asked in the case of Hungarian literature or social sciences as well. We have to reemphasize the generational difference: those who stepped into adulthood around and after 1990, having had such a different life experience, have other priorities.

But let us make a small detour towards sociology and sociography. Bulcsu Bognár (2006) recalled Niklas Luhmann's almost apocalyptic vision, in his Die Gesellschaft der Gesellschaft, published in 1998, in the introduction of which Luhmann says "no important development has happened in Sociology in the area of social sciences in the last hundred years since the time of the classic founding fathers", and thus follows a past-oriented approach that evokes the classics. Luhmann continuously complains that sociology mostly produces empty talk and data, which in fortunate cases turns into literary forms rather than producing some general theory. He suggests taking impulses from other disciplines, a strategy he calls 'nomadic behaviour'. This means that sociologists have to migrate to places where something useful, some new and deep sources, can be found. Let them travel. (Nevertheless, Luhmann envisioned an abstract migration, himself being a classic ivory tower academic who has never been away from his study for more than three days.)

What is Hungarian sociology capable of, what route should it take, what are its national or regional characteristics (if any), and what should it concern itself with? These questions are often asked. In June 1991, not long after the change of regime, during a conference of the Hungarian Sociological Society, György Csepeli and Anna Wessely spoke about the cognitive potential of Central European sociology (Csepeli and Wessely, 1992): how could Hungarian sociology be presented in an era of newly increased interest in East European societies, where is its place, and how should sociology be done in this new context? They argued that we need to stay in touch with the specific Hungarian/Central European social experience, which allows us to do sociology as no one else does. This means that intellectuals and academics also have a duty to work out social reform programmes. Finally they expressed their confidence that we won't be robbed of this cognitive opportunity, and will turn into interpreters between the two parts of Europe.

In the following debate some questioned whether such a program could be successful, and whether sociology can play a significant role in shaping public life. Hungary's place between East and West is relevant again, especially in everyday politics. Though sociology has become professionalized in the last 25 years, as new departments and research institutes have opened in cities around the country. ${ }^{2}$

Public opinion polls took place even during the socialist period, and after the change of regime many such companies appeared on the market. Meanwhile sociologists debated the nature of measuring in social sciences in the journal Replika Vol. 1991, No. 2-3, and interviews were published about the professionalization of sociology in the same issue.

\footnotetext{
${ }^{2}$ In Budapest, the capital city, this already started in the 1960 s, when sociology was no more declared as a bourgeois pseudo-science, even if the communist party elite still looked upon sociologists with suspicion, fearing them to be dissidents and critics of the regime (Gábor, 1992).
} 
Before 1990 some thought that sociology came into fashion because it broke away from 'the terror of ideology'. In the 50s this science was silenced - says Tibor Kuczi (1991) - but poetry became more popular; the latter "juxtaposed subjective perception and validity of experience" with the all-knowing nature of the regime (1991: 70-71). In 1994, Júlia Szalai and Pál Tamás wrote about the crisis in (Hungarian) sociology (Tamás, 1994). After 1990, sociography resurfaced, and here we need to jump back a bit to the beginning of the 20th century, to the first attempts in Hungarian social sciences, and the commitment of social scientists to social reforms and political engagement. World War I disrupted this process, and Hungarian sociology turned into a black sheep between the two world wars because many of the so-called radical sociologists had been active during the period of the Hungarian Soviet Republic in 1919. However, within the Hungarian Ethnographic Society a social science section was formed in 1920, which founded the journal Társadalomtudomány. At an institutional level, sociology has remained part of the university structure, and sub-disciplines of sociology have continued to develop (Saád, 1996).

We need to recall this because this was a time when the writer came on stage in the role of sociographer. Dénes Némedi overviews this issue in his key monograph (1985), emphasizing that at the turn of the century there was a theoretical need, that they wanted to learn about reality, but this need to reform society was intertwined with political ambitions. Thus the role of academic and politician had already merged before 1914 (1985: 9-11). At the same time, the European assessment that writers and intellectuals cannot be supporters of the ruling regime or of the bourgeoisie became widely accepted in the rejuvenated Hungarian literature of the beginning of the century (1985: 14). But from 1920 on, in Horthy's Hungary, this sort of literary 'opposition' was restrained, and some of writers tried to get closer to power (1985: 14). The movement of the so-called folk or rural writers begins at this point, also the 'urban' vs. 'folk' debate, but among the folk writers the leftists were dominant, focusing on the 'people', the peasants and the village instead of the 'rotten city', because only they can rejuvenate Hungary. "Moral and national, that is: folk" became the alternative they searched for (1985: 16). This form of social research became a movement in the 1930s: the sociographer is dedicated, and it is not professionalism that matters, but rather serving the national goals of the people, beyond daily politics (1985: 17).

Hungarian social science thinking was characterized by essayism, which became widespread exactly because of developmental dysfunctions in institutional academe and due to its backwardness. The major work of the period is Gyula Illyés' A puszták népe (1936), which is today taught as a transition between Sociology and Literature. It is a description of society, which merges elements of scientific and artistic description. But primarily it can be considered a confession-like reminiscence which familiarizes us with the misery and deep poverty of bonded workers living on the Hungarian puszta. Some of the 'folk writers' thought in a resigned way that it would not be the village folk, the peasantry, who would 'save' the country. Gábor Gyáni says, quoting Némedi and Bognár, that this kind of special sociography cannot be considered an academic venture because it describes society on a confessional basis (based on the author's own experience). Thus, even though some, like Erdei, had academic 
ambitions and methods, sociographers between the two world wars produced literature rather than academic work (Gyáni, 2013a).

Some of the rural writers, and people like Ferenc Erdei who also dealt with theoretical issues, became part of or subservient to the power structure after the end of World War II and the Communist take-over.

Amidst the super-optimism of the new world, descriptions of the remaining or apparently newly-emerged problems were not welcome in the one-party system, and during the repression following the 1956 revolution many writers were imprisoned. The question remained of who would write about what is happening, or what was happening. Gyáni points out that "though novel and history differ from each other, from some novels one learns more about the past than from the historical sources". Gyáni mentions John Lukacs, a historian of Hungarian origin living in the US, according to whom Édes Anna [Dezső Kosztolányi, 1926] better describes the 19191920 counter-revolution period than historians do. However, Gyáni criticises this approach by stating that those who say such things have not done research in the area of social history or of the history of mentality (Gyáni, 2013b).

Thus we cannot say that literature can replace history or social sciences as such, but there is a tradition of a socially embedded and politically engaged literature, one which is confusing, problematic, and inspiring all at the same time. The question, to follow Gyáni, is if those novels have social relevance, and what their influence is on social research.

\section{Hungarian literature and society yesterday and today}

So-called Kadarism (named after its defining political character, János Kádár) stretched from 1957 to 1989. This era was characterised by what is called double-talk: one could speak about social problems, but this could not be paired with any open criticism of the regime. György Konrád, who was noted as a sociologist as well as a short-story writer and novelist, published his A látogató (The Visitor) in 1969, considered to be the new starting point for Hungarian literature. In this novel, Konrád writes about his experiences as an official of the child protection authorities in the capital. In the novel, the official has to take care of a child whose parents committed suicide. The book is a picture of an era after the defeat of the revolution, of the apocalyptic, grey world of the 60)s, but the appearance of suicide is also an important element, as Hungary had stood at the top of world-wide suicide statistics since the 1960s.

Thus, important sociographies were written, in parallel with the institutionalization of sociology, like Zsolt Csalog's ones about the Roma - which counted as a criticism of the dictatorship. The worker-writer Sándor Tar chronicled the poor and hopeless living on the margins of society. He also wrote about the guest workers of the former German Democratic Republic (1976), and about workers commuting to Budapest (1978). Péter Hajnóczy, who also began as a worker, managed to provoke the regime with his sociography Elkülönítö (Quarantine) (1978), which dealt with mental patients, healthcare and alcoholism, all increasingly relevant 
in that era. (Hajnóczy died in 1981, at the age of 39, himself a victim of alcoholism and drug addiction.)

Though a central image of Hungarian writers is related to self-destruction (alcoholism, cigarettes, irregular lifestyle, etc.) which is often linked to the national tragedy (what else to do in a dictatorship except drink like the Russians?...), and while the author himself is worried for the nation, the era also produced another type of author (not to mention the darlings of the regime). It was György Aczél, the defining cultural policy-maker, who introduced the policy of the three Ts: tilt, tür, támogat (meaning: ban, tolerate, support). György Moldova was one of the originally tolerated, later supported writers who wrote sociographies based on commissions from the ministry. He is still active, and since the change of regime has published even more in almost all genres: with more than a hundred books and more than 15 million total copies, ${ }^{3}$ his is a unique achievement not just in the Hungarian context. It is the paradox of the era that with the permission and support of the ministries he explored some segments of reality, delivering an apology for and criticism of the regime at the same time, writing about the miners, about the difficult situation facing the workerwomen in the textile industry, about the hopeless situation of the railways, about smuggler truck-drivers, or about the police and crime. His reportage novel, Bün az élet (Life is a crime, 1988), was commissioned by the Ministry of the Interior; he received information from the ministry, which later turned out to be false. It was published in more than half a million copies in a country of ten million, and while it paradoxically described how a police state was turning into a state based on the rule of law, with the policemen in it continuing to violate the law, his uncritical reporting of anti-Roma statements would contribute to the spreading of anti-Roma sentiments and misconceptions, especially to the spreading of the concept of 'Roma crime', referring to it as a constantly increasing and significant phenomenon, suggesting that "crime is in their blood", and that the Roma do not want to work. In vain do sociologists and anthropologists prove day by day that this concept lacks any basis in fact.

\section{What can be done?}

New themes have recently emerged in sociographical literature. Gyula Szilágyi’s sexual-sociological sociographies tell of the sexual lives of people from the region beyond the Tisza river, about their everyday culture (Szilágyi, 2005), of the loneliness of people living in big cities, and their sexual lives (Szilágyi, 2007).

We would merely point to some recent works here, like Zoltán Tábor's sociography Cigány rulett (Roma Roulette) (2014) which is a reportage book, a social description in the style of a literary novel, written about eleven settlements where a series of racist murders took place in 2008-2009, killing six Roma and injuring five. We learn not about the attackers who chose their victims randomly, but about the

\footnotetext{
${ }^{3}$ On this oeuvre, see Révész, S. (2013a) Kritikai szervilizmus - Moldova György pályaképe I. (Critical Servilism - György Moldova’s Biography I). Magyar Narancs, (48) November 28. and Révész, S. (2013b) A nemzeti szellem megtestesítője - Moldova György pályaképe II. (The Embodier of National Spirit György Moldova’s Biography II). Magyar Narancs, (50) december 12.
} 
coexistence of 'Hungarians' and 'Roma', about the lagging, vegetating settlements, it is about people, Roma and non-Roma unemployment, about life strategies, hopelessness; all this is important in connection to the increasingly widespread and hatred-inducing phenomenon of Hungarian national radicalism.

So the role of writer and sociographer have become merged again, and if this does not involve a false need for nation-saving, or the distortion of the past, these works can certainly contribute to the construction of a non-distorted historic memory, to identity formation and to the perception of reality. The relationship of literature to sociology can be more complex than we think, and while the former can be inspired by the latter, the results and methodology of the latter can also help the former. László Szilasi, who published his much acclaimed novel in 2014 (Szilasi, 2014a), said in an interview (Szilasi, 2014b) that he had done fieldwork for the book, which is about a homeless person, and that his aim was to turn public attention to this problem because "literature is a specific form of consciousness, it communicates things which none else does, and moreover it does so in a world in which images dominate over texts” (Gaál, 2015).

The adverse lives of the countryside have in the last decade appeared in the works of Krisztián Grecsó, who belongs to the younger generation. In his novels, István Kerékgyártó writes about the privatization crimes related to the change of regime, the 'nouveau riche', and about homelessness, ministerial corruption and the decline of certain social strata in Budapest; László Garaczi's autobiographical novels tell of the often absurd situations of Hungarian life since the 1960s. Lajos Grendel relates the life of Hungarians in Slovakia in a unique tone, while László Végel that of Hungarians in Vojvodina. György Dragomán hails from Romania, and his works describe the sinister socialism in Romania, while another author from Transylvania, Ádám Bodor, also shows us fates hopeless in a distinctly East European way, even if his world is often an abstract one.

Ferenc Barnás' A kilencedik (The Ninth, 2006) and Szilárd Borbély's Nincstelenek (The Dispossessed, 2013), both write about the deep poverty of the 60s and 70s, and each could equally take place in a Hungarian village today, just with even less chance for their characters to break out. Poverty was deep even at that time, but most of the people could feel that they did not just live from one day to the next, that, even if in slow steps, they could grow, and perhaps their children could go on to college.

Barnás and Borbély break away from the representation of poverty as the literature of the 19th and beginning of the 20th century (Margócsy, 2014; Bíró-Balogh, 2014) constructed it, namely that the poor man is the real, honest Hungarian, who preserves his sense of national belonging, that his poverty is organic, authentic, that in fact it matches the Hungarian character, unlike the Western bourgeois lifestyle which only weakens national identity (moreover, the bourgeoisie and capitalism and business-making are usually linked to the Germans and the Jews; we should not forget that until the $1850 \mathrm{~s}$ in Budapest, the so-called 'city of sin', more people spoke German than Hungarian).

Being poor is not a strength anymore, and the village world, especially the male one, is aggressive, with alcohol all-pervading. It is a taboo topic that Jews were deported with the help of local villagers, and that their property was ransacked. 
Pál Závada began as a sociologist, writing sociographies of family and village history about his own native village (Závada, 1986); he later wrote about the Hungarian, Slovak and Jewish population of his village in Békés county. His latest novel (2014), the 620-page Természetes fény (Natural Light) is an enormous enterprise supplemented with contemporary photographs from the pre-World War II era, from WWII itself, and the years closely following WWII. This literary work is also a social ethnography, and social, economic and minority history, ethnography, sociography; borders are washed away, but it is definitely a novel. Reality gets mixed up with fictitious elements, more narrators tell the story, which is the story of the war, the Holocaust, and the story of crimes committed by Hungarian soldiers on the territory of the former Soviet Union. But we can also read about how unwillingly villagers received the Jews returning from concentration camps, or how the Slovaks in Hungary, becoming nationalists in the coma of the war, were resettled in place of the Hungarians deported from Slovakia, how they changed their identity there, and later how they remembered all these events. It is a huge historical tableau which serves as an important addition to many popular research topics, such as remembering and forgetting, historical memory and its questions, how these intertwine with identity and contemporary nationalisms, or the radicalization of certain social groups in crisis situations.

Let us say a few words about writing for the theatre, too. Some playwrights not only discuss the most acute problems, and do not simply describe the present situation, but also break important taboos. Such is the work of Csaba Székely's Bánya trilógia (Mine trilogy), describing the rough world of Transylvanian villages inhabited by Hungarians and Romanians, where alcohol prevails, and where the immorality of the priests is also portrayed on stage. András Urbán from Serbia, active in the ethnic Hungarian theatre of Szabadka (Subotica), is not only a socially engaged author, but also examines topics such as the relationship to WWII (in the play Neoplanta) or the question of state borders, the relationships between Hungarians living on the two sides of the Serbian-Hungarian border, as well as their relations with the Serbs (Passporttrilogy): questions of identities and mutual representations. Urbán, before directing his trilogy, made his actors conduct (quasi-)sociological studies, interviewing people of different nationalities, professions, and ages, e.g. about the Hungarian-Hungarian relationship.

Béla Pintér's theatre is characterised by his excellent humour, but also for his sensitivity to problems such as healthcare services, mental illness, alcoholism, parental roles, abortion, orphancy, collaboration and problem of informants during socialism (one still unresolved in Hungarian politics and public opinion), the relationship of media and politics, the arts, folk music and folk world, evangelism, and the new evangelical churches (Pintér, 2013).

\section{On the advantages and disadvantages of history}

Since Nietzsche (but not just him) this self-reflexive question is more present in social sciences than in natural sciences: historians, sociologists, writers etc. cannot just pass by the history of their field (Némedi, 1996). 
According to Nietzsche, as is well known, the study of history is needed, and, as Dénes Némedi put it: "the legitimacy of sociology in its classic period, in fact until the 70 s, was supported by the way it saw itself competent on the subject of society, considered both as an integrative framework and as the set of issues conceived as 'problems'. Sociology is also needed, thought many at the beginning of the century, because there are many phenomena and 'problems' which cannot be grasped in medical-hygienic, economic or political terms. Primarily, it is about poverty and all the 'problems' related to it: deviance, segregation based on place of living, and so on." According to the historian of sociology, the question of advantage/disadvantage, and thus of its legitimacy, was not an issue till the 70s.

Do sociology, sociography and literature still contribute to individual and/or collective self-understanding, or are they redundant because they are not able to participate in social change?

Hungarian literature and sociography played a leading role in breaking taboos and exploring social reality. Meanwhile writers, intellectuals and creative people were constantly exposed to attacks from the regime - a familiar phenomenon in the whole region of Central-Eastern Europe and the Balkans. Until 1990 their persecution was continuous almost everywhere: in more fortunate cases they were forced to emigrate, while in other cases they were imprisoned or 'only' prevented from working and forced to survive as physical workers or unemployed. Nowadays one does not hear about such cases: anyone can write or research whatever they want (if they have the funds to do so), but their writings often do not reach their readers, or the mainstream, and public media is silent about their findings. This kind of silence and exclusion from the public media is a form of censorship, which, ultimately, signals that the regimes in power in this region find critical intellectuals dangerous.

And the real question is an eternal one: can reality be grasped, how is society and within it the writers, sociologists, or the mass media - able to describe itself? In general, what does it mean to observe it, and can the description of what has been observed be considered a description of reality? In short: how does the "construction of reality" works? One can understand the 'war' between actors on the political scene, and also between the actors on the intellectual and artistic scene: what is at stake is who is to say what 'reality' is.

Sociology and literature have the advantage, though, that unlike mass media, which is controlled, influenced, and manipulated by politics, they are not built on schemes, are not produced on the basis of scripts, nor does they force news (or facts) into pre-set frames, but always search for something new. 


\section{References}

Bíró-Balogh, Tamás (2014) Szegényekben gazdag irodalom (Literature Rich in Poor People). Paper presented at the conference on poverty held by the journal 2000 . Budapest, December 5.

Bognár, B (2006) Nemzeti szociológiák klasszikus szociológiája (The Classical Sociology of National Sociologies). Szociológiai Szemle, (1): 103-115.

Csepeli, Gy. and A. Wessely (1992) A közép-európai szociológia kognitív esélye (The Cognitive Prospects of Central European Sociology). Replika, (1-2): 1-7.

Gaál, B. (2015) Szilasi László: A harmadik híd egy ismeretlen társadalomba vezet. http://szegedma.hu/hir/szeged/2015/02/szilasi-laszlo-a-harmadik-hid-egyismeretlen-tarsadalomba-vezet.html

Gyáni, G. (2013) Nemzet, kollektív emlékezet és public history (Nation, Collective Memory and Public History). In Gyáni, G. (ed.) Nép, nemzet, zsidó (People, Nation, Jew). Bratislava: Kalligram. 173-210.

Gyáni, G. (2013a) A paraszti individualizáció Erdei Ferenc felfogásában (The Peasant Individualization in Ferenc Erdei’s perception). In Gyáni, G. (ed.) Nép, nemzet, zsidó (People, Nation, Jew). Bratislava: Kalligram. 42-70.

Gyáni, G. (2013b) Falusi elidegenedés avagy individualizáció Németh László Gyász című regényében (Rural alienation or individualization in László Németh's novel, Gyász). In Gyáni G. (ed.) Nép, nemzet, zsidó (People, Nation, Jew). Bratislava: Kalligram. 28-41.

Hamvay, P. (2015) „Nincs többé elegancia” - Morcsányi Géza, a Magvető Kiadó leköszönő igazgatója ('No more elegance' - Géza Morcsányi, resigning director of Magvető Kiadó). Magyar Narancs, (10) March 5.

Kuczi, T. (1991) „Magánnyelv” - szociológia - közbeszéd („Personal Language” Sociology - Common Talk). Replika, (2-3): 69-80.

Kukorelly, E. (2014) Országházi divatok (Parliamentary Fashions). Budapest: Libri.

Margócsy, I. (2014) Nincstelenség és sorstalanság a kortárs irodalomban (Poverty and Fatelessness in Contemporary Literature). Paper presented at the conference on poverty held by the journal 2000. Budapest, December 5 .

Némedi, D. (1985) A népi szociográfia 1930-1938 (FOLK SOCIOGRAPHY 1930-1938). Budapest: Gondolat.

Némedi, D. (1996) Minek a történet? (What is History for?). Replika, (23-24): 173181.

Pintér, B. (2013) Drámák (Dramas). Budapest: Saxum.

Révész, S. (2013a) Kritikai szervilizmus - Moldova György pályaképe I. (Critical Servilism - György Moldova’s Biography I). Magyar Narancs, (48) November 28. 
Révész, S. (2013b) A nemzeti szellem megtestesítője - Moldova György pályaképe II. (The Embodier of National Spirit - György Moldova’s Biography II). Magyar Narancs, (50) december 12.

Réz, P. (2015) Nem olyan jó a magyar irodalom (Hungarian Literature is Not That Good). Magyar Narancs, September 04, http://magyarnarancs.hu/konyv/rez-palnem-olyan-jo-a-magyar-irodalom-91619 Accessed 10-03-2015

Schein, G. (2014) Esernyők a Kossuth téren (Umbrellas in Kossuth Square). Pécs: Jelenkor.

Sebald, W. G. (2014) Légi háború és irodalom: A rombolás természetrajza. (Air War and Literature: On the Natural History of Destruction). Budapest: Európa.

Saád, J. (1996) Magyar szociológia-történet: minek a története? (Hungarian History of Sociology: What's History?) Replika, (23-24): 161-173.

Gábor, K. (1992) A magyar szociológia intézményesüléséről: Interjú Huszár Tiborral (On the Institutionalization of Hungarian Sociology: Interview with Tibor Huszár). Replika, (1-2): 31-47.

Szilágyi, Gy. (2005) Tiszántúli Emanuelle (Emanuelle from the Trans-Tisza Region). Budapest: Osiris Kiadó.

Szilágyi, Gy. (2007) Nagyvárosi Emanuelle (Emanuelle from the City). Budapest: Mérték Kiadó Kft.

Szilágyi, Zs. (2009) Rendszerváltás Abszurdisztánban (Change of Regime in Absurdistan). Kortárs, (6) http://www.kortarsonline.hu/regiweb/0906/szilagyi.htm Accessed 10-03-2015

Szilasi, L. (2014a) A harmadik híd (The Third Bridge). Budapest: Magvetö.

Szilasi, L. (2014b) Drezda bombázása: 1975. (Bombing of Dresden: 1975). Élet és Irodalom, (51-52): 20.

Tábor, Z. (2014) Cigány Rulett (Roma Roulette). Budapest: Európa Könyvkiadó.

Tamás, G. M. (2015) Kikérem Magamnak (I Object). HVG, February 25, http://hvg.hu/velemeny.nyuzsog/20150225_TGM_Kikerem_magamnak Accessed 25-02-2015

Tamás, P. (1994) A sündisznó és a súrolókefe. Szociológia és társadalmi gyakorlat az új Kelet-Európában (The hedgehog and the scrub brush. Sociology and Social Practice in the New Eastern Europe). In Kemény I. and L. Gábor (eds.) $X X X$. 1963-ban alakult meg a Szociológiai Kutatócsoport. Budapest: MTA Szociológiai Int. MTA Társ. Konfliktusok Kut. Közp. 327-350.

Závada, P. (1986) Kulákprés. Család- és falutörténeti szociográfia. Tótkomlós 19451956 (Kulákprés. Family and Village Historical Sociography). Budapest, 1986.

Závada, P. (2014) Természetes fény (Natural Light). Budapest: Magvető. 